\title{
Overriding Phthalate Decomposition When Exploring Mycophenolic Acid Intermediates as Selenium-Based ROS Biological Probes
}

\author{
Mahesh B. Halle,$^{\dagger, \perp}$ Tesla Yudhistira, ${ }^{\dagger, \perp}$ Kyung Jin Lee, ${ }^{\S, \perp}$ Jae Hyuck Choi, ${ }^{\dagger, \dagger}$ Youngsam Kim, ${ }^{\dagger, \|}$ \\ Hee-Sung Park, ${ }^{\S}$ and David G. Churchill $*^{\dagger,+\infty}$ \\ ${ }^{\dagger}$ Department of Chemistry, Molecular Logic Gate Laboratory, and ${ }^{\S}$ Department of Chemistry, Molecular Synthetic Biology \\ Laboratory, Korea Advanced Institute of Science and Technology (KAIST), Daejeon 305-701, Republic of Korea \\ *Center for Catalytic Hydrocarbon Functionalization, Institute for Basic Science (IBS), Daejeon 305-701, Republic of Korea
}

\section{Supporting Information}

ABSTRACT: Hypochlorous $\left(\mathrm{OCl}^{-}\right)$acid is the most well-known bacterial oxidant to be produced by neutrophils. Excess amounts of $\mathrm{OCl}^{-}$can cause various disorders in living systems. Herein, we have designed, synthesized, and characterized two novel organoseleniumbased target molecules (Probe-1 and Probe-OCl) based on a synthetic intermediate of mycophenolic acid for the aqueous detection of $\mathrm{OCl}^{-}$. Probe 1 has been recently reported (Org. Lett. 2018, 20, 3557-3561); both probes show immediate "turn-on" fluorescence $(<1 \mathrm{~s})$ upon the addition of $\mathrm{OCl}^{-}$, display an increase in the fluorescence quantum yield (3.7-fold in Probe-1 and 11.6fold in Probe-OCl), and are completely soluble in aqueous media without the help of any cosolvent. However, a decrease in the "turnon" intensity with the oxidized version of Probe- 1 in cell assays due

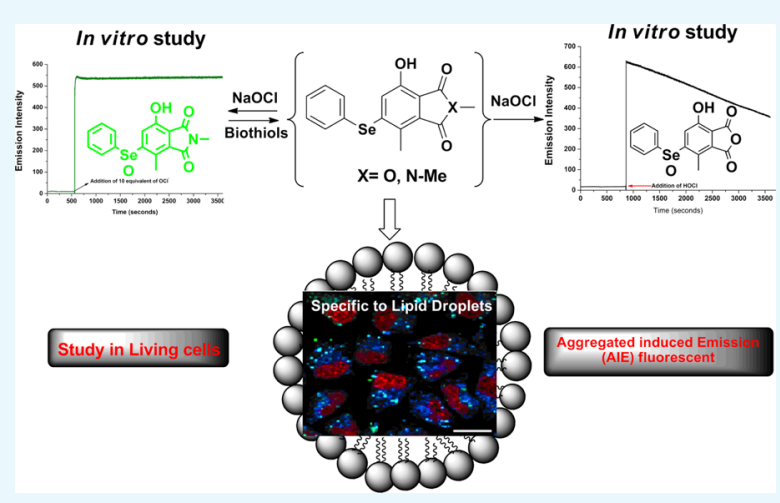
to the anhydride/phthalate functionality suggests that probe degradation occurs based on hydrolytic action (a probe degradation half-life of $\sim 1500 \mathrm{~s}$ at $15 \mu \mathrm{M}$ Probe-1 and $150 \mu \mathrm{M}$ $\mathrm{OCl})$. Thus, the change of "anhydride" to "methylamide" begets Probe-OCl, which possesses more stability without sacrificing its water solubility properties and responses at short times. Further studies suggest that Probe-OCl is highly stable within physiological $\mathrm{pH}(\mathrm{pH}=7.4)$. Surprisingly, in live cell experiments involving U-2 OS cells and HeLa cells, Probe-OCl accumulated and aggregated in lipid droplets and gives a "turn-on" fluorescence response. 3-(4,5-Dimethylthiazol-2-yl)-2,5diphenyltetrazolium bromide assays confirmed that Probe-OCl is not toxic. Cuvette aggregation studies were also performed (tetrahydrofuran $/ \mathrm{H}_{2} \mathrm{O}$ ) to demonstrate aggregation-induced fluorescence at longer times. Our current hypothesis is that the "turn-on" fluorescence effect is caused by the aggregation-induced emission mechanism available for Probe-OCl. In this case, in tandem, we reanalyzed the Mes-BOD-SePh derivative to compare and contrast cell localization as imaged by confocal microscopy; fluorescence emission occurs in the absence of, or prior to, Se oxidation.

\section{INTRODUCTION}

In recent years, many researchers have been focusing on the development and optimization of optical and visualization methods to discern the plethora of important small-molecule analytes such as metal cations, anions, and biologically active neutral or zwitterionic molecules [biothiols and reactive oxygen species/reactive nitrogen species (ROS/RNS)] that are created and exist within the biological system. ${ }^{1}$ To achieve this aim, many precise analytical methods have been developed, which involve methods and systems such as potentiometric, ${ }^{2}$ coulometric, colorimetric methods, ${ }^{3}$ and quantum dot media. ${ }^{4}$ Because there is no perfect sensor, the quest to synthesize a soluble medium that is small molecule in nature and also bears other excellent attributes including selectivity, sensitivity, reusability, etc. is still being undertaken. These methods have several drawbacks such as high detection limits [limit of detection (LOD)] and require relatively long times for acquisition of results or extensive procedures, as well as expensive instruments to obtain a quantitative result. On the other hand, fluorescence methods have many advantages: they are specific, sensitive toward specific analytes, easy to handle, and have a high temporal and spatial resolution, thus accommodating the possibilities for both in vitro and in vivo bioimaging. ${ }^{5-8}$ Currently, the majority of fluorophores which have been synthesized address problems such as complex or difficult syntheses, large molecular size, and poor solubility; hence, these factors limit the applications of the fluorophore in fluorescence labeling and functionalization. Among the reported organic dyes, maleimide derivatives offer various promising properties, such as high emissivity, large Stokes shifts, water solubility, and ease of modification with many functional groups. $8 \mathrm{~b}$

Received: July 8, 2018

Accepted: October 5, 2018

Published: October 18, 2018 
Through continuous research efforts, more research results have emerged regarding ROS/RNS and its important role in maintaining the physiological and biological processes of the human body. ${ }^{9-11}$ Among other ROS/RNS, hypochlorous acid $\left(\mathrm{OCl}^{-}\right)$is a highly potent oxidant generated during phagocytosis that serves as a pathogen "killer" within the immune system. ${ }^{12,13} \mathrm{OCl}^{-}$is one of the most biologically important $\mathrm{ROS}$; $\mathrm{OCl}^{-}$is produced by the myeloperoxidase enzyme in leukocytes (macrophages, monocytes, and neutrophils), and the reaction between chloride $\left(\mathrm{Cl}^{-}\right)$and $\mathrm{H}_{2} \mathrm{O}_{2}$ gives $\mathrm{OCl}^{-14-19}$ The $\mathrm{OCl}^{-}$species, an oxidizing agent of great renown, can undergo reaction with biothiol groups (cysteine, homocysteine, and glutathione) and thioethers (such as methionine) within cells. ${ }^{20,21}$ Because of this action, an excess in concentration of $\mathrm{OCl}^{-}$in biological systems can lead to inflammation-associated tissue damage and a series of lifethreatening diseases, such as neurodegenerative disease [i.e., Alzheimer's disease $(\mathrm{AD})]^{22}$ atherosclerotic, ${ }^{23-25}$ cardiovascular disease, ${ }^{26,27}$ hepatic ischemia-reperfusion injury, ${ }^{28,29}$ lung injury, ${ }^{30}$ and cancer; ${ }^{31}$ therefore, the development of new biocompatible classes of molecules that can help for use in highly sensitive and selective ROS fluorescent probes in living systems is vitally important.

To date, a number of fluorescent small molecules have been synthesized and characterized to detect $\mathrm{HOCl}^{32-35}$ However, the real-time detection of $\mathrm{HOCl}$ in a biological system remains a challenge. ${ }^{36-38}$ The presence of a cosolvent, ${ }^{39}$ low sensitivity, poor photostability and/or chemostability (possibly photobleaching or facile S-E bond cleavage), and long response time, for example, in some cases hinder the actual use in biological systems. ${ }^{40}$ Over a period of decades, extensive efforts have been put forth to develop highly selective fluorescent probes for the imaging of ROS at the cellular level. The precise measurement of concentrations of ROS in living systems is a challenging proposition, and chemosensing with excellent selectivity and high sensitivity is the tool in need, which can be employed for the present goal. Many strategies were used to detect $\mathrm{HOCl}$ based on its high reactivity; compounds containing thiol, ${ }^{41,42}$ oxime, ${ }^{43-45}$ dibenzoylhydrazine, ${ }^{46} p$ methoxyphenol, $^{47,48}$ and organochalcogen (, , Se, and Te) units $^{49-53}$ have been used. They have displayed highly responsive properties upon oxidation that can be used as HOCl-reactive moieties.

Lipid droplets (LDs) are organelles in cells whose size varies between 20 and $100 \mathrm{~nm}$; LDs conserve and maintain the production of neutral lipids such as steryl esters, triglycerides, and retinyl esters in the cells (eukaryotic and some prokaryotic). ${ }^{54-56}$ LDs can be identified by their hydrophobic central core which is surrounded by a single layer of amphiphilic lipids and proteins, which separate between the aqueous and organic layers. ${ }^{57}$ LDs may be found accumulated in the cytoplasm of cells, especially in cells which are responsible for the trafficking and protein maturation. ${ }^{58}$ LDs are well-known for their important role in the human immune system such as to modulate the stability of proteins and for exchanging the protein. In addition, LDs are known as a powerhouse for synthesizing molecules important for defense against pathogens such as eicosanoids. Besides that, LDs also help convert overabundant fatty acids into triglycerides in order to separate healthy and toxic fatty acids and keep them housed within relatively inert LDs. ${ }^{59}$ Recent studies suggest that lipid oxidation products increase in the brains of $\mathrm{AD}$ patients and may involve a significant increase in the concentration of LDs in many diseases characterized by the abnormal concentration of lipid supply and metabolism. ${ }^{60,61}$ LD buildup in cells can occur during the progression of pathologies such as neuropathies, cardiomyopathies, or during liver inflammation caused by the human immunodeficiency virus. ${ }^{62}$ The development and progression of several common metabolic diseases such as obesity, type II diabetes, atherosclerosis, and Chanarin-Dorfman syndrome have been associated with the abnormality in neutral lipid storage. ${ }^{63}$ Despite their proposed strong relationship to many diseases, our knowledge of LDs is still quite limited. ${ }^{63 \mathrm{~b}}$

In continuation of our efforts directed toward the development of molecular probes involving phenyl selenide groups as reactive substituents, we recently reported a novel meso mesitylene-BODIPY system. This system contains a chloroand phenyl selenide at the 2- and 6-positions, respectively, which can react specifically toward $\mathrm{HOCl}$ in vitro and also supply a "turn-on" fluorescence in the presence of LD living cells because of aggregation-induced emission (AIE) ${ }^{51}$ The effect of other substituents on the BODIPY system during the detection of $\mathrm{HOCl}$ was also investigated. ${ }^{51,53,64}$

Even though many application studies have been achieved using phthalate molecules and anhydride derivatives, ${ }^{65}$ to the best of our knowledge, anhydride and amide phenyl selenide conjugates have never been investigated in such fluorescence studies; here, we pursue selective, water-soluble, and lowmolecular-weight detection of $\mathrm{HOCl}$ in vitro and demonstrate a "turn-on" response. Because of the susceptibility of phthalates to decomposition, Probe-OCl was investigated in detail despite its apparent vulnerability. ${ }^{66-68}$ Further studies in living cells also demonstrated that Probe-OCl has the ability to accumulate within LDs and act with "turn-on" fluorescence signaling prior to Se oxidation and gives rise to fluorescence because of the AIE effects.

\section{RESULTS AND DISCUSSION}

The syntheses of Probe- $\mathbf{1}^{66}$ and Probe- $\mathbf{O C l}$ are outlined in Scheme 1 for comparison. The starting materials were synthesized according to a known literature procedure. The diene product underwent reaction with phenylselenyl chloride in the presence of acetonitrile and water and then undergoes a Diels-Alder reaction to form Probe-1 and Probe-OCl in good yield (51 and 62\%), respectively. The structures of Probe-1

Scheme 1. Synthesis of Probe- $1^{66}$ and Probe-OCl for $\mathrm{HOCl}$
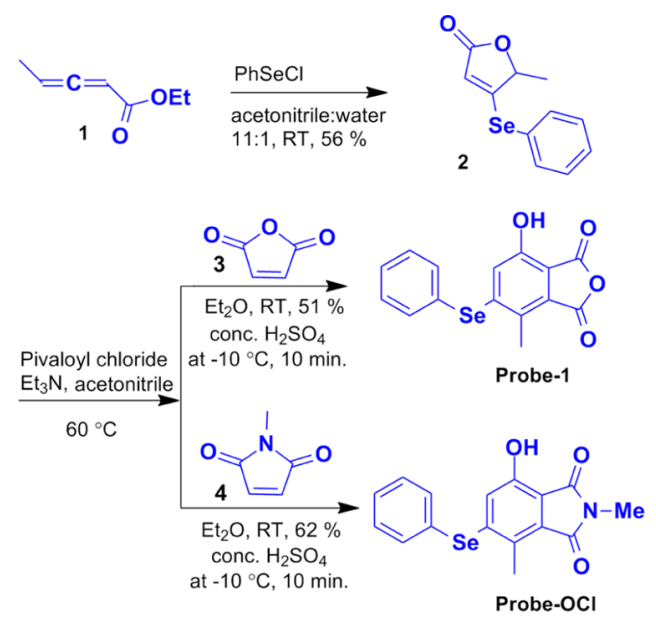
and Probe-OCl were characterized by spectroscopic techniques [multinuclear nuclear magnetic resonance (NMR) spectral data, mass spectrometry (MS), and Fourier transform infrared (FT-IR), Figures S4-S18, Supporting Information].

Results from the study of UV-visible spectroscopy of Probe-1 and Probe-OCl are shown in the Supporting Information (Figures S19 and S24). The spectroscopy analysis of Probe-1 and Probe-OCl (15 $\mu \mathrm{M}$ in $10 \mathrm{mM}$ PBS, $\mathrm{pH} 7.4)$ is explained in Table 1. Both probes show a "turn-off" emission

Table 1. Properties of Probe- 1 and Probe-OCl in Solution upon Addition of 10 equiv of $\mathrm{OCl}^{-}(10 \mathrm{mM}$ PBS, pH 7.4) Incubated for $1.0 \mathrm{~min}$

\begin{tabular}{lllll}
\multicolumn{1}{c}{ compounds } & $\lambda_{\mathrm{abs}}{ }^{a}$ & $\lambda_{\mathrm{em}}{ }^{b}$ & $\phi^{c}$ & $\Delta \lambda^{d}$ \\
Probe-1 & 402 & 495 & 0.063 & 93 \\
Probe-1[O] & 404 & 502 & 0.23 & 98 \\
Probe-OCl & 396 & 512 & 0.032 & 116 \\
Probe-OCI[O] & 416 & 523 & 0.37 & 107
\end{tabular}

${ }^{a}$ Absorption wavelength $(\mathrm{nm}) .{ }^{b}$ Emission wavelength $(\mathrm{nm}) .{ }^{c}$ Fluorescence quantum yield. ${ }^{d}$ Stokes shift $(\mathrm{nm})$.

because of the incorporation of the phenylselenyl group at the 2-position of the probe, which quenches the fluorescence by an intramolecular photoinduced electron-transfer (PET) process and gives a "turn-on" fluorescence after the addition of $\mathrm{OCl}^{-}$ (Figure 1).

Both probes inherit identical photophysical properties and selectivity toward $\mathrm{OCl}^{-}$. However, Probe-1 is not as stable as Probe-OCl (Figures S19-S23, Supporting Information). We observed that upon the addition of $\mathrm{OCl}^{-}$, the emission of Probe-1 gradually decreased over time as observed in the time-

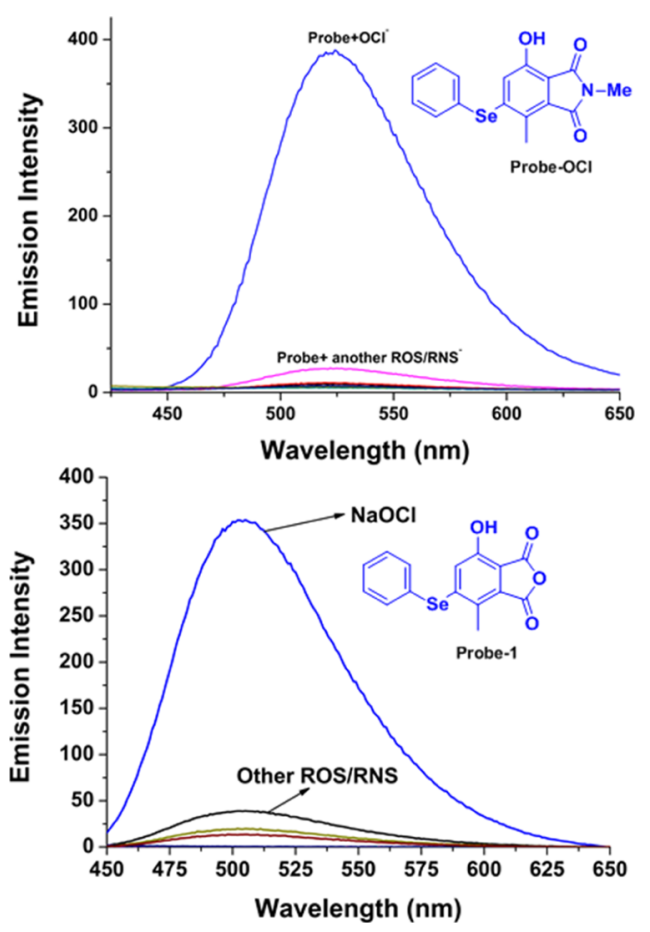

Figure 1. Comparison of emission spectral changes of Probe-1 (15 $\mu \mathrm{M})$ and Probe-OCl $(15 \mu \mathrm{M})$ with various ROS in solution $[10 \mathrm{mM}$ phosphate-buffered saline (PBS) $\mathrm{pH}$ 7.4] incubated for $5 \mathrm{~min}, \lambda_{\mathrm{ex}}$ : $404 \mathrm{~nm}, \lambda_{\mathrm{em}}: 502 \mathrm{~nm}$ (Probe-1); $\lambda_{\mathrm{ex}}: 416 \mathrm{~nm}, \lambda_{\mathrm{em}}: 523 \mathrm{~nm}$ (Probe$\mathrm{OCl})$. Slit width $3.0 \mathrm{~nm} / 3.0 \mathrm{~nm}$. dependent experiment (Figure 2A). This could likely occur because of the instability of the anhydride functional group in
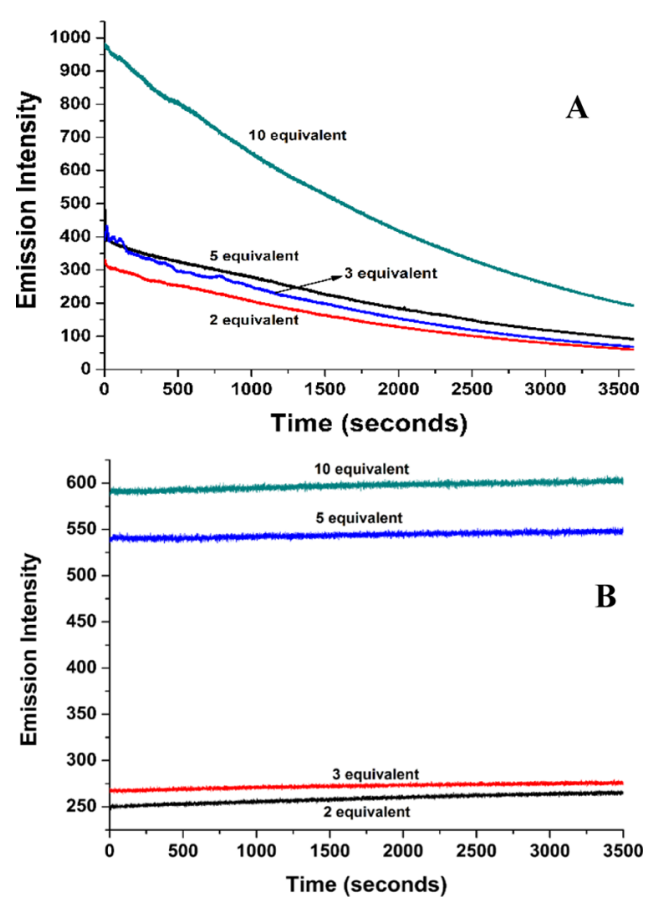

Figure 2. Comparison of time-dependent emission spectra of [A] Probe-1 $(15 \mu \mathrm{M})$ and [B] Probe-OCl $(15 \mu \mathrm{M})$ with various concentrations of $\mathrm{NaOCl}$ in solution (10 mM PBS pH 7.4) incubated for $3600 \mathrm{~s}, \lambda_{\text {ex }}: 404 \mathrm{~nm}, \lambda_{\mathrm{em}}: 502 \mathrm{~nm}$ (Probe-1); $\lambda_{\mathrm{ex}}: 416 \mathrm{~nm}, \lambda_{\mathrm{em}}: 523$ $\mathrm{nm}$ (Probe-OCl). Slit width $3.0 \mathrm{~nm} / 3.0 \mathrm{~nm}$.

the aqueous or cellular environment. We suspected that the anhydride motif within Probe-1 undergoes hydrolysis/ degradation; thus, decreasing the emission of the resulting molecule proposed to be due to $\mathrm{C}-\mathrm{O}$ bond rupture and anhydride ring opening and resulting in no loss of the ability for Se to become singly oxidized/oxygenated. Probe-1 and perhaps its depleted form are less likely to aggregate, and our thinking is that the $\mathrm{C}-\mathrm{O}$ cleavage tendency is only likely to make the tendency for aggregation decrease. On the other hand, the incorporation of methylamide within the skeleton of Probe-OCl affords a much greater stability to Probe-OCl as suggested in the time-dependent experiment (Figure 2B). The stability of Probe-OCl opens the possibility for Probe-OCl to be applied suitably in live cell imaging.

First, we investigated the photophysical properties of ProbeOCl. UV-visible absorption spectra show the maximum absorption at $396 \mathrm{~nm}$. However, upon the addition of $\mathrm{OCl}^{-}$ (1.0 equiv) to Probe-OCl, the absorbance peak undergoes a red shift (toward longer wavelength) to $416 \mathrm{~nm}$, whereas after the addition of other ROS/RNS, no significant change in the absorption spectra of Probe-OCl could be observed (Figure S24, Supporting Information). The selectivity of Probe-OCl toward various $\mathrm{ROS} / \mathrm{RNS}\left(\mathrm{NaOCl}, \mathrm{H}_{2} \mathrm{O}_{2},{ }^{t} \mathrm{BuOOH}, \mathrm{O}_{2}{ }^{\bullet-}\right.$, ${ }^{\circ} \mathrm{OH},{ }^{t} \mathrm{BuO}^{\bullet}, \mathrm{NO}$, and $\mathrm{ONOO}^{-}$) was conducted under physiological conditions of the human body in $10 \mathrm{mM}$ PBS, $\mathrm{pH}$ 7.4. At a concentration of $15.0 \mu \mathrm{M}$, Probe- $\mathrm{OCl}$ showed selectivity toward $\mathrm{OCl}^{-}$(Figure $3 \mathrm{~A}$ ); there is no increase in the fluorescence intensity toward other ROS/RNS even when higher concentrations of other ROS/RNS (20 equiv) were made available. The addition of $\mathrm{NaOCl}$ to Probe- $\mathrm{OCl}$ gives a 

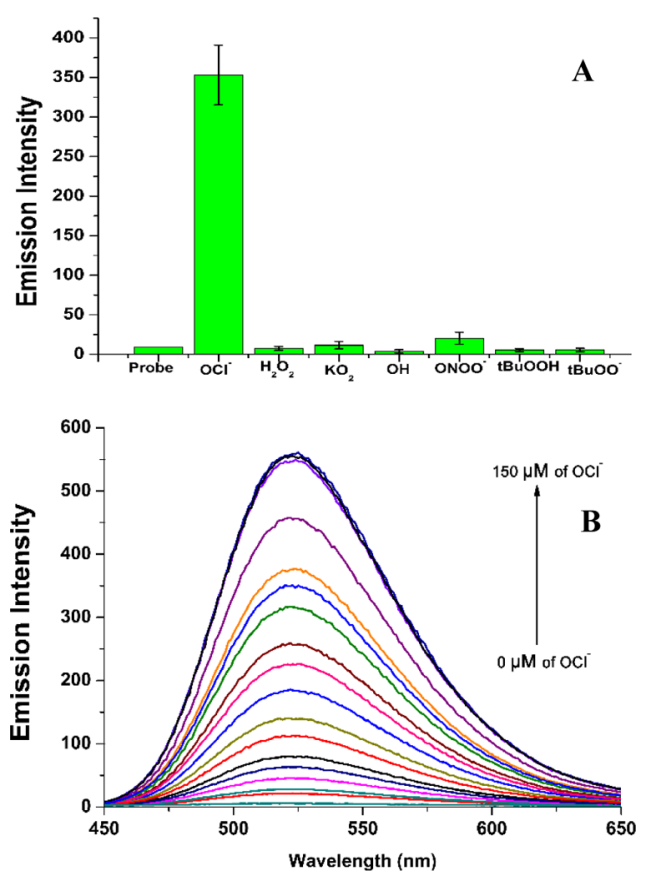

Figure 3. [A] Bar graph depiction of fluorescence emission of ProbeOCl $(15 \mu \mathrm{M})$ with $\mathrm{NaOCl}, \mathrm{H}_{2} \mathrm{O}_{2},{ }^{t} \mathrm{BuOOH}, \mathrm{O}_{2}{ }^{\bullet-},{ }^{\bullet} \mathrm{OH},{ }^{t} \mathrm{BuO}{ }^{\bullet}, \mathrm{NO}$, and $\mathrm{ONOO}^{-}$. [B] Increase of emission spectra of Probe-OCl (15 $\mu \mathrm{M})$ with various concentrations of $\mathrm{NaOCl}(0-150 \mu \mathrm{M})$ in solution (10 mM PBS, pH 7.4) incubated for $1.0 \mathrm{~min} . \lambda_{\mathrm{ex}}: 416 \mathrm{~nm}, \lambda_{\mathrm{em}}: 523$ $\mathrm{nm}$. Slit width $3 \mathrm{~nm} / 3 \mathrm{~nm}$.

rise in emission centered at $523 \mathrm{~nm}$ with the enhancement of fluorescence intensity gauged at $\sim 30$ fold. The fluorescence quantum yield $\left(\Phi_{\mathrm{F}}\right)$ of Probe-OCl was found to be 0.032 , related to the assigned PET process involving the incorporation of the phenylselenyl group. However, the addition of the $\mathrm{NaOCl}$ analyte allowed for a significant increase in the quantum yield (up to 0.37 ) because of the formation of ProbeOCl[O] (Scheme 2).

Scheme 2. Reversible Oxidation Mechanism for the Detection of $\mathrm{NaOCl}$
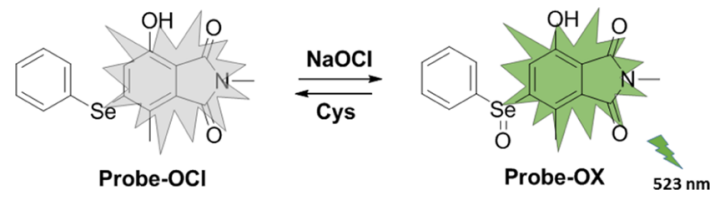

Next, the interference study of $\mathrm{OCl}^{-}$with other ROS/RNS was employed. This suggested that the excess of different oxidants does not serve in an additive fashion. The results clearly showed that the other ROS/RNS did not give any observable optical changes in the emission spectrum (Figure S27, Supporting Information). Since the presence of even a small aliquot of metal ion solution at high dilution with ProbeOCl may serve as interference for the sensor and therefore for the reaction and the desired operation of the probe with $\mathrm{OCl}^{-}$. We first added various soluble metal ions in the solution of Probe-OCl $(15.0 \mu \mathrm{M})$, followed by $\mathrm{OCl}^{-}$(5.0 equiv). This result shows that the metal ions did not interfere with ProbeOCl (Figure S28, Supporting Information).

In order to monitor $\mathrm{OCl}^{-}$in macrophage cells, Probe-OCl should remain stable in a slightly acidic environment without eliciting any fluorescence response. Hence, we tested the response of Probe- $\mathrm{OCl}$ toward $\mathrm{OCl}^{-}$at various $\mathrm{pH}$ levels (Figure 4). The results reveal that, as expected, the $\mathrm{pH}$ value of

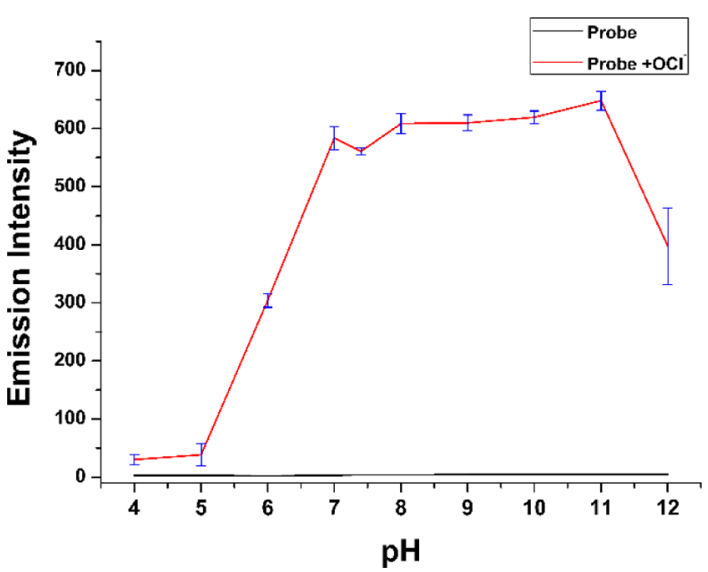

Figure 4. Changes of the emission spectra of Probe-OCl $(15 \mu \mathrm{M})$ with $\mathrm{NaOCl}$ (10 equiv) under various $\mathrm{pH}$ conditions in solution (10 mM PBS, pH 7.4) incubated for $1.0 \mathrm{~min} \lambda_{\mathrm{ex}}: 416 \mathrm{~nm}, \lambda_{\mathrm{em}}: 523 \mathrm{~nm}$. Slit width $3.0 \mathrm{~nm} / 3.0 \mathrm{~nm}$.

the solution has an influence on the fluorescence response to $\left[\mathrm{OCl}^{-}\right]$. As shown in Figure 3, the fluorescence intensity at $523 \mathrm{~nm}$ of the Probe- $\mathrm{OCl}$ response to $\mathrm{OCl}^{-}$was gradually enhanced when the $\mathrm{pH}$ increased in the range of 6.0-7.0; it reached the maximum intensity in the range of 7.4-11.0. However, in the $\mathrm{pH}$ range of 4.0-5.0, the probe did not respond to $\mathrm{OCl}^{-}$; we did not observe any fluorescence enhancement in this $\mathrm{pH}$ region (4-5) because of the $\mathrm{pH}$ effect toward Probe-OCl detection. The trend of fluorescence intensity changes of Probe- $\mathbf{O C l}$ at $523 \mathrm{~nm}$ demonstrates that the probe can tolerate a slightly acidic environment; because of this, it is suitable to detect $\mathrm{OCl}^{-}$in living media and cellular subcompartments such as macrophage cells.

Titration of Probe-OCl with the increase of the concentrations of $\mathrm{NaOCl}(0-150 \mu \mathrm{M})$ was carried out; the experiments supported that the emission intensity of ProbeOCl proportionally increases upon the addition of $\mathrm{NaOCl}$ from 0 to 10 equiv (Figure 3B). The fluorescence of ProbeOCl reached emission saturation after the addition of 9 equiv of $\mathrm{NaOCl}$. Further study showed that the LOD of the probe was determined to be $90 \mathrm{nM}$ (Figure S27, Supporting Information).

The time-dependent study of Probe-OCl and Probe-1 was carried out simultaneously with the addition of 10 equiv of $\mathrm{NaOCl}$. Probe-OCl shows a very fast response upon the addition of $\mathrm{NaOCl}$ and gives a strong green fluorescence just after the addition of $\mathrm{NaOCl}$ (Figure 5). On the other hand, we observed a rapid decrease in the emission intensity with Probe-1. The time-dependent experiments of Probe-OCl indicate that Probe-OCl reacts very fast with $\mathrm{OCl}^{-}$; this result opens up the possibility of Probe-OCl to be used as a real-time sensing agent in the cellular level.

It has been known that $\mathrm{OCl}^{-}$has an ability to oxidize selenium to selenoxide in aqueous, as well as in organic solvent, media. We hypothesized that $\mathrm{OCl}^{-}$will clearly oxidize selenium to selenoxide under sufficient concentrations of analyte. In order to help confirm the reaction mechanism, the characterization of the oxidized species was carried out by high-resolution MS (HRMS) data of Probe-OCl with $\mathrm{OCl}^{-}$ 


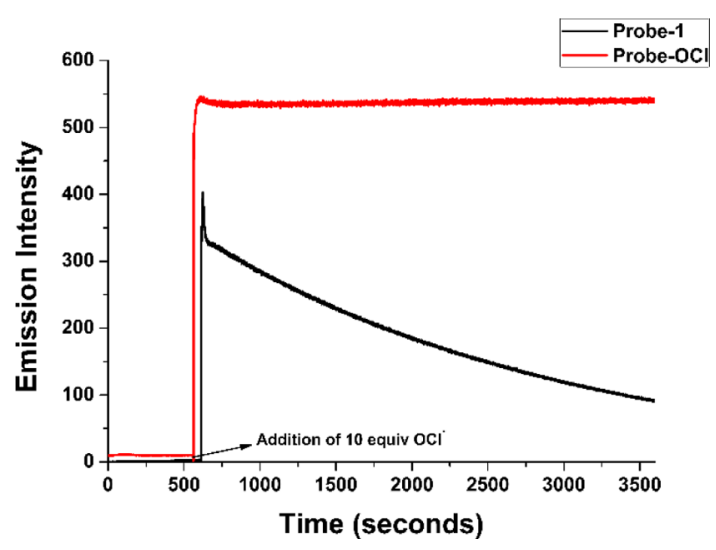

Figure 5. Comparative time-dependent emission spectra of ProbeOCl $(15 \mu \mathrm{M})$ and Probe-1 $(15 \mu \mathrm{M})$ with the addition of 10.0 equiv of $\mathrm{NaOCl}$ in the $10 \mathrm{mM}$ PBS pH 7.4, followed by incubation for 3000 s; $\lambda_{\mathrm{ex}}: 404 \mathrm{~nm}, \lambda_{\mathrm{em}}: 502 \mathrm{~nm}$ (Probe-1) $\lambda_{\mathrm{ex}}: 416 \mathrm{~nm}, \lambda_{\mathrm{em}}: 523 \mathrm{~nm}$ (Probe-OCl). Slit width $3.0 \mathrm{~nm} / 3.0 \mathrm{~nm}$.

(5.0 equiv). The $\mathrm{m} / z$ peak at 385.9843 (found) is consistent with the selenoxide version of Probe-OCl [385.9907 (calcd) $\left[\mathrm{M}+\mathrm{Na}^{+}\right]$(Figure S16, Supporting Information). In addition, we observed the shift in the ${ }^{77}$ Se NMR spectrum from 399.4 to $985.3 \mathrm{ppm}$, which is related to the oxidation of selenide (Figure S12, Supporting Information). Accordingly, the formation of the selenoxide blocks electron transfer from the phenyl selenide donor moiety to Probe-OCl, which results in a blocking of the PET process and an increase in the emission intensity of the probe. These HRMS data support that selenoxide formation has occurred after the addition of $\mathrm{OCl}^{-}$ to the Probe-OCl solution (Scheme 2).

To investigate the reversibility of the chemical oxidation, Probe-OCI $[\mathbf{O}]$ was treated with biothiols such as glutathione, homocysteine, $\mathrm{N}$-acetyl-L-cysteine, and L-cysteine, which has an ability to revert the selenium oxide species $\left(\mathrm{R}_{2} \mathrm{Se}=\mathrm{O}\right)$ to its original reduced state $\left(\mathrm{R}_{2} \mathrm{Se}\right) .^{70,71}$ The result (Figure 6)

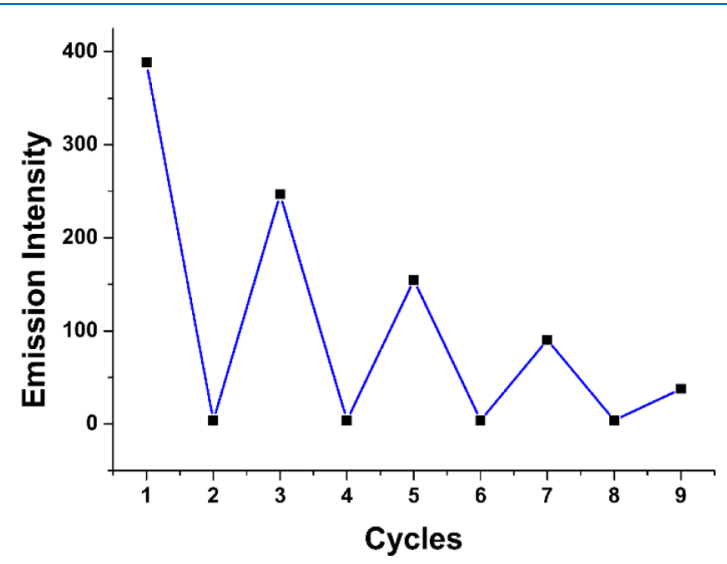

Figure 6. Reversibility of the oxidized Probe-OCl $(15 \mu \mathrm{M})$ with the addition of 10 equiv of L-cysteine after $5 \mathrm{~min}$ in solution (10 mM PBS $\mathrm{pH}$ 7.4). $\lambda_{\mathrm{ex}}: 416 \mathrm{~nm}, \lambda_{\mathrm{em}}: 523 \mathrm{~nm}$. Width $3.0 \mathrm{~nm} / 3.0 \mathrm{~nm}$.

showed a significant decrease in the fluorescence intensity with glutathione, L-cysteine, and homocysteine. In the case of glutathione and homocysteine addition, oxidized Probe-OCl gives a "turn-off" fluorescence signal after $5 \mathrm{~h}$ of incubation time involving a screening that simulates the sequence of several redox cycles (Figure S33, Supporting Information).
Surprisingly, the addition of L-cysteine into oxidized ProbeOCl gives a "turn-off" fluorescence within $5 \mathrm{~min}$ and the redox cycles can be repeated four times. ${ }^{53}$ This result indicates that Probe-OCl has reversibility attributes desirable for nextgeneration probing.

To confirm the nature of the photomechanism at play, density functional theory (DFT) geometry optimization calculations were performed. Optimized structures were estimated by DFT calculations using the Gaussian 09 program. The B3LYP functional with a 6-31g* basis set was used, and the 6-311g* basis set was used only for Se; all calculations were performed in the gas phase (Figure S28, Supporting Information). As observed by considering the geometry of the optimized structure of Probe-OCl and Probe-OCI $[\mathrm{O}]$, the case of these two kinds of molecular orbital electron density maps is surprising; they seem almost the same and are without the involvement of the selenyl position. Also, the difference in energy between the highest occupied molecular orbital (HOMO) and lowest unoccupied molecular orbital (LUMO) of DFT-optimized geometries of probe and oxidized probe is almost the same. Differences of electronic distributions were observed in the case of HOMO - 2, HOMO, and LUMO +1 orbitals. In parts of electronic distributions for HOMO -2 , LUMO +1 , the phenylselenium moiety does not possess electronic distribution density, and in the HOMO segment, all of the electronic distributions involved the phenylselenium moiety. Therefore, HOMO-toLUMO electronic distributions changed from being directly on the phenylselenium moiety to being on the center of the naphthalimide moiety. On the other hand, the electron transfer from phenylselenium to the naphthalimide core of the chemically oxidized probe could have occurred more effectively than for the probe because the electronic distributions seen in the HOMO -2 , HOMO, LUMO + 2 level overlapped with phenylselenium from the naphthalimide core (Figure S29, Supporting Information). From these results, the fluorescence "turn-on" event could be explained by a blockage of the PET that would ordinarily exist between phenylselenium and the naphthalimide core occurring from the oxidation of the selenium center (Table S3, Supporting Information).

To further demonstrate the applicability of Probe-OCl, 3(4,5-dimethylthiazol-2-yl)-2,5-diphenyltetrazolium bromide (MTT) assays were performed. Probe-OCl was found to be nontoxic to cells and did not interfere with cell proliferation (Figures S31 and S32, Supporting Information). To examine prospective biological applications of Probe-OCl, U-2 OS (Figure 7) and HeLa cells (Figure S32, Supporting Information) were chosen for live cell imaging. DRAQ5 was used to costain the nucleus of the cells; 4',6-diamidino-2phenylindole and Alexa-488 were used because of the similar range of excitation wavelength with Probe-OCl and MesBOD-SePh. Then, U-2 OS cells were treated with Probe-OCl, followed by a $10 \mathrm{~min}$ incubation period, and the cells were expected to exhibit low fluorescence based on the presence of the synthetic molecule. Surprisingly, a strong fluorescent dot pattern was observed (Figure 7A). Then, we compared the Se results with those from our previous work using BODIPY mesitylene functionalized at the so-called meso-position (MES-BOD-SePh). ${ }^{51}$ We conclude that the fluorescence observed could be caused by the aggregation of the probe within a LD, as the images showed a similar pattern and overlapped with the previous developed MES-BOD-SePh, 


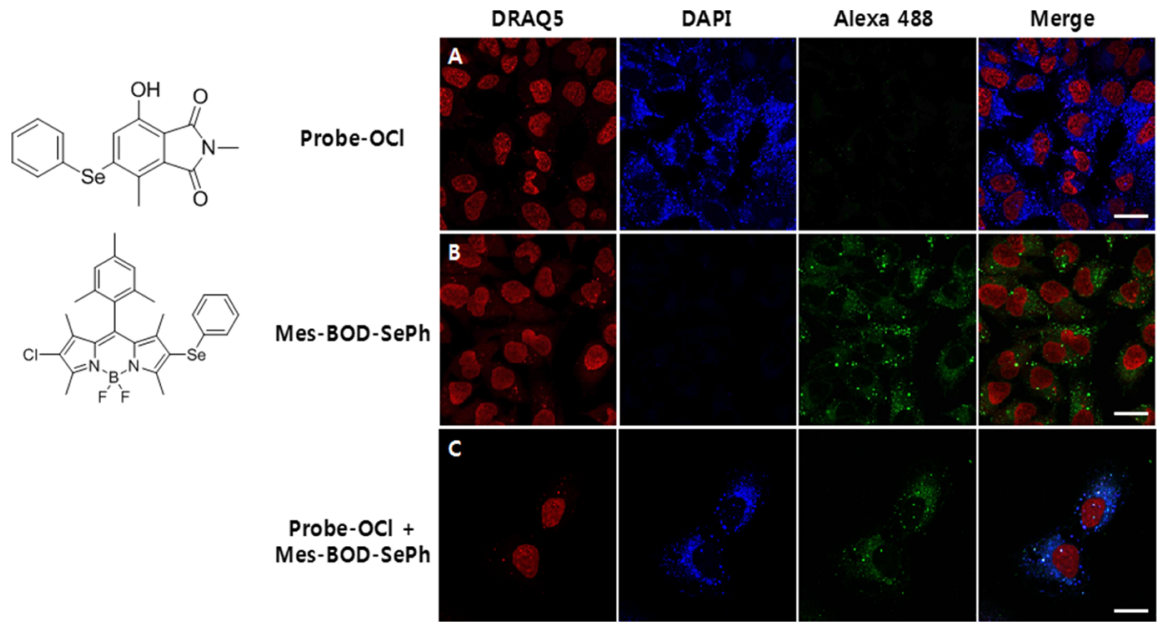

Figure 7. Fluorescence imaging in live U-2 OS cells labeled with Probe-OCl and Mes-BOD-SePh [A]. Cells were incubated for 10 min with 25 $\mu \mathrm{M}$ Probe-OCl (blue, Ex/Em 405/500) in PBS [B] and $25 \mu \mathrm{M}$ Mes-BOD-SePh (green, Ex/Em 488/530) [C] and coincubated for 10 min. Probe-OCl signals were consistent with LD staining dye MES-BOD-SePh. Scale bar, $10 \mu \mathrm{m}$.
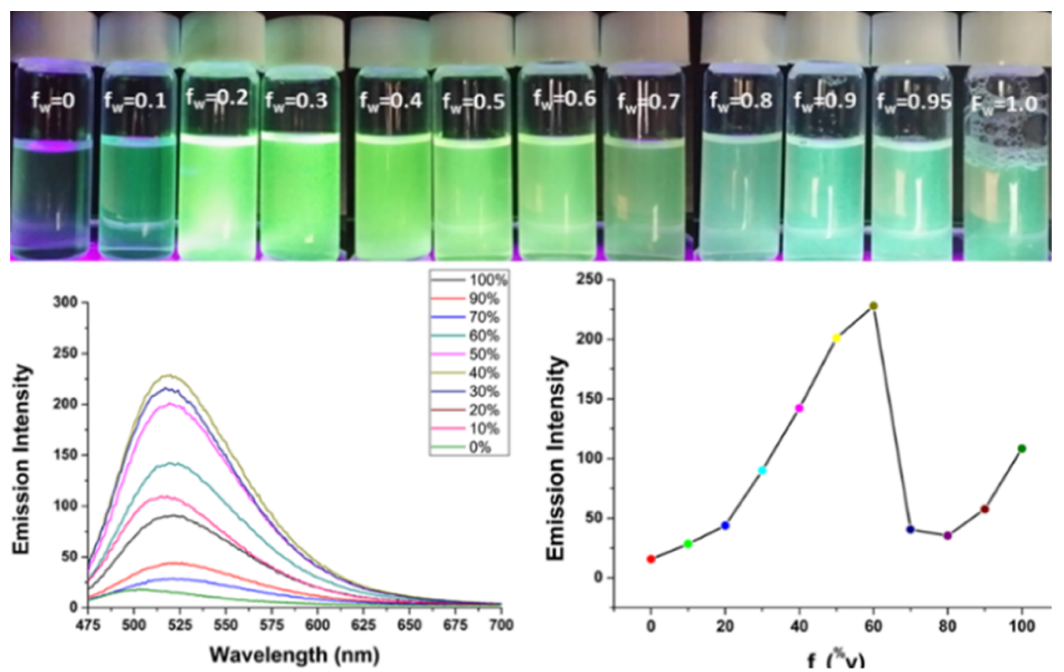

Figure 8. Fluorescence spectra of Probe-OCl $(15 \mu \mathrm{M})$ in THF/water mixtures with different water fractions and plot of emission intensity vs water fraction. Fluorescence images at $f_{\mathrm{w}}=0-100 \%$. Incubated for $6 \mathrm{~h} \lambda_{\text {ex }}: 416 \mathrm{~nm}, \lambda_{\mathrm{em}}: 523 \mathrm{~nm}$. Width $3.0 \mathrm{~nm} / 3.0 \mathrm{~nm}$.

which selectively targets the LDs (Figure 7B). Furthermore, to confirm that our Probe-OCl selectively targets LDs, both probes were counterincubated and observed to overlap in their signals and fluorescence characteristics (Figure 7C).

The AIE feature of Probe-OCl was investigated in a tetrahydrofuran (THF)/water mixture, by measuring the increase of the fluorescence emission spectrum of ProbeOCl (Figure 7). Probe-OCl exhibited weak emission in THF; there is no increase in the emission intensity up to a 9:1 (v/v) THF/water mixture. Surprisingly, we observed a significant increase in the emission intensity in a THF/water mixture when a ratio of $4: 6$ is used (Figure 8). The fluorescence intensity decreased dramatically and reached the lowest intensity measured when the water fraction reached $\sim 80 \%$. However, when the water fraction reached $\sim 90 \%$, the fluorescence intensity increased. These optical changes are attributed to twisted intramolecular charge-transfer effects arising from increased solvent polarity as seen through a solvent system that is gradually increasing in its portion of water. $^{67}$ The addition of water can effectively influence the present conditions of Probe-OCl; therefore, Probe-OCl possesses AIE properties.

\section{CONCLUSIONS}

In summary, two fluorescent probes, Probe-1 and Probe-OCl, were scrutinized and compared in new cellular media and directly prepared and characterized based on a synthetic intermediate of mycophenolic acid for the specific detection of hypochlorous acid ( $\mathrm{HOCl})$. Both probes showed sensitive, selective, and fast responses to $\mathrm{HOCl}$ over other ROS/RNS because of the oxidation of selenide to selenoxide. Both probes showed immediate "turn-on" fluorescence responses ( $<1 \mathrm{~s})$ upon the addition of $\mathrm{OCl}^{-}$and showed an increase in their quantum yield (3.8-fold in Probe-1 and 11-fold in ProbeOCl); they are completely soluble in aqueous media without the help of any cosolvent. Further studies showed that Probe-1 is unstable in a water environment at longer times and undergoes what could be categorized as fluorescence photobleaching. Therefore, we incorporated methylmaleimide within Probe-OCl to help increase the stability of the compounds. The superiority of Probe-OCl includes high sensitivity, 
specificity, and rapid "turn-on" fluorescence response for $\mathrm{HOCl}$ under physiological pH. Surprisingly, when Probe-OCl was studied in living cells (U-2 OS cells and HeLa cells), MTT assays confirmed that Probe-OCl is not toxic. Probe-OCl undergoes AIE in LDs. We reanalyzed the Mes-BOD-SePh derivative for a comparative localization of probes. Probe- $\mathrm{OCl}$ was reported to be a probe for LDs as seen in cuvette aggregation and induced fluorescence based on the addition of $\mathrm{OCl}^{-}$but lacks stability-based hydrolytic action of water (probe degradation with a half-life of $\sim 1500 \mathrm{~s}$ at $15 \mu \mathrm{M}$ Probe-1 and $150 \mu \mathrm{M} \mathrm{OCl}$ ). Thus, the change of "anhydride" to "methylamide" - an interesting substitution to explore in medicinal chemistry-led us to investigate Probe-OCl. This system is more appropriate, and this phenomenon helped make determinations within the range of physiological $\mathrm{pH}$ and based on associated attributes such as stability than compared with Probe-1.

\section{EXPERIMENTAL SECTION}

General Considerations. All chemicals were used without further purification and purchased from commercial sources (Aldrich, Tokyo Chemical Industry). ${ }^{1} \mathrm{H},{ }^{13} \mathrm{C},{ }^{77} \mathrm{Se}$ NMR spectra were acquired using a Bruker Avance 400 and AgilentNMR-vnmrs $600 \mathrm{MHz}$ spectrometer. Tetramethylsilane (TMS) and dimethyl selenide were used as external standards. ESI-MS was performed on a Bruker micrOTOF-QII by the research support staff at KAIST. A time-of-flight mass spectrometer was operated at a resolution of 20000 . Absorption spectra and stopped-flow absorption spectra were measured using a JASCO V-530 and JASCO-815 UV-vis spectrophotometer, respectively. Fluorescence measurements were carried out with a Shimadzu RF-5301pc spectrofluorophotometer.

Synthesis of 1 (5-Methyl-4-(phenylselanyl)furan-2(5H)one). ${ }^{66,69}$ A solution of ethyl penta-2,3-dienoate $(0.400 \mathrm{~g}, 3.17$ $\mathrm{mmol})$ in $\mathrm{MeCN}(6 \mathrm{~mL})$ was subsequently added to $1 \mathrm{~mL}$ of $\mathrm{H}_{2} \mathrm{O}$, which was then added to a well-stirred solution of $\mathrm{PhSeCl}(0.912 \mathrm{~g}, 4.75 \mathrm{mmol})$ in $5 \mathrm{~mL}$ of $\mathrm{MeCN}$ at room temperature. Then, the resulting mixture was stirred at room temperature for $2 \mathrm{~h}$. The mixture was then evaporated directly and purified by column chromatography on silica gel (petroleum ether/ethyl acetate 10:2) to afford 5-methyl-4(phenylselanyl)furan-2 $(5 H)$-one $(0.450 \mathrm{~g}, 56 \%)$ as a yellow oil, as reported previously. ${ }^{1} \mathrm{H} \mathrm{NMR}\left(600 \mathrm{MHz}, \mathrm{CDCl}_{3} / \mathrm{TMS}\right): \delta$ 7.66-7.59 (m, 2H, $\left.\mathrm{H}_{8}, \mathrm{H}_{12}\right), 7.50-7.44\left(\mathrm{~m}, 1 \mathrm{H}, \mathrm{H}_{10}\right), 7.44-$ $7.37\left(\mathrm{~m}, 2 \mathrm{H}, \mathrm{H}_{9}, \mathrm{H}_{11}\right), 5.47\left(\mathrm{~d}, \mathrm{~J}_{\mathrm{H}-\mathrm{H}}=1.4 \mathrm{~Hz}, 1 \mathrm{H}, \mathrm{H}_{3}\right), 5.09$ $\left(\mathrm{qd}, J_{\mathrm{H}-\mathrm{H}}=6.7,1.4 \mathrm{~Hz}, 1 \mathrm{H}, \mathrm{H}_{5}\right), 1.50\left(\mathrm{~d}, J_{\mathrm{H}-\mathrm{H}}=6.7 \mathrm{~Hz}, 3 \mathrm{H}\right.$, $\left.\mathrm{H}_{6}\right) ;{ }^{13} \mathrm{C}$ NMRS $\left(150 \mathrm{MHz}, \mathrm{CDCl}_{3}\right): 170.8\left(\mathrm{C}_{2}\right), 135.9$ $\left(\mathrm{C}_{8,12}\right), 130.2\left(\mathrm{C}_{9,11}\right), 130.1\left(\mathrm{C}_{4,10}\right), 124.7\left(\mathrm{C}_{7}\right), 115.7\left(\mathrm{C}_{3}\right)$, $80.7\left(\mathrm{C}_{5}\right), 20.2\left(\mathrm{C}_{6}\right) ;{ }^{77} \mathrm{Se} \mathrm{NMR}\left(76.5 \mathrm{MHz}, \mathrm{CDCl}_{3}\right)$ : 384.67; IR $\left(\mathrm{CHCl}_{3}\right) \nu_{\text {max }}: 3019,2931,1743,1572,1540,1521,1477$, $1440,1320,1216,1166,1086,1056,1022,932,908,883,844$, $753 \mathrm{~cm}^{-1} ; \mathrm{mp}=141-142{ }^{\circ} \mathrm{C}$.

Synthesis of Probe-1 (7-Hydroxy-4-methyl-5(phenylselanyl)isobenzofuran-1,3-dione). A solution of triethylamine $(0.438 \mathrm{~mL}, 3.14 \mathrm{mmol})$ in acetonitrile $(5 \mathrm{~mL})$ was added dropwise to a solution of 5-methyl-4-(phenylselanyl)furan-2 $(5 \mathrm{H})$-one $(0.400 \mathrm{~g}, 1.57 \mathrm{mmol})$ and trimethylacetyl chloride $(0.387 \mathrm{~mL}, 3.14 \mathrm{mmol})$ in acetonitrile $(10 \mathrm{~mL})$, and the mixture was stirred at $60{ }^{\circ} \mathrm{C}$ for $14 \mathrm{~h}$. The precipitate of triethylamine hydrochloride was formed, precipitated, and filtered away. The filtrate was then washed with $10 \%$ sodium carbonate, dried over $\mathrm{MgSO}_{4}$, and concentrated. The residue was concentrated and filtered through silica gel using petroleum ether/EtOAc (4:1) to afford the diene as a colorless oil. This was used directly for the next reaction. The abovementioned diene $(0.390 \mathrm{~g}, 1.15 \mathrm{mmol})$ and maleic anhydride $(0.136 \mathrm{~g}, 1.38 \mathrm{mmol})$ were dissolved in diethyl ether $(3 \mathrm{~mL})$ under $\mathrm{N}_{2}$ and stirred overnight. Concentrated $\mathrm{H}_{2} \mathrm{SO}_{4}(1.5 \mathrm{~mL})$ at $263 \mathrm{~K}$ was added slowly to this resulting sticky liquid product. The cream-colored mixture was stirred for $5 \mathrm{~min}$ and then poured over crushed ice. The precipitated product was filtered off, washed by the addition of ice water, dried, and concentrated. The residue was purified by silica gel flash column chromatography using $n$-hexane/EtOAc $(3: 2)$ as an eluent to afford Probe-1 $(0.260 \mathrm{~g}, 51 \%)$ as a yellow solid. ${ }^{1} \mathrm{H}$ NMRS $\left(600 \mathrm{MHz}, \mathrm{CDCl}_{3}\right): \delta 7.64-7.61\left(\mathrm{~m}, 2 \mathrm{H}, \mathrm{H}_{12}, \mathrm{H}_{16}\right)$, 7.52-7.49 (m, 1H, $\left.\mathrm{H}_{14}\right), 7.47-7.44\left(\mathrm{~m}, 2 \mathrm{H}, \mathrm{H}_{13}, \mathrm{H}_{15}\right), 6.74(\mathrm{~s}$, $\left.1 \mathrm{H}, \mathrm{H}_{6}\right), 2.63\left(\mathrm{~s}, 3 \mathrm{H}, \mathrm{H}_{10}\right)$; ${ }^{13} \mathrm{C}$ NMR $\left(100 \mathrm{MHz} \mathrm{CDCl}_{3}\right)$ : $164.2\left(\mathrm{C}_{1}\right), 162.4\left(\mathrm{C}_{3}\right), 153.5\left(\mathrm{C}_{7}\right), 152.2\left(\mathrm{C}_{8}\right), 136.7\left(\mathrm{C}_{12,16}\right)$, $131.1\left(\mathrm{C}_{5}\right), 130.4\left(\mathrm{C}_{13,15}\right), 130.1\left(\mathrm{C}_{14}\right), 127.3\left(\mathrm{C}_{9}\right), 125.9$ $\left(\mathrm{C}_{11}\right), 122.7\left(\mathrm{C}_{6}\right), 111.7\left(\mathrm{C}_{4}\right), 15.0\left(\mathrm{C}_{10}\right) ;{ }^{77} \mathrm{Se}$ NMR $(76.5$ $\left.\mathrm{MHz}, \mathrm{CDCl}_{3}\right): 430.68$; IR $\left(\mathrm{CHCl}_{3}\right) \nu_{\text {max }}: 3472,3020,2928$, $1835,1757,1622,1465,1440,1405,1369,1293,1215,1166$, 1039, 980, 908, $756 \mathrm{~cm}^{-1}$; $\mathrm{mp}=189-192{ }^{\circ} \mathrm{C}$; MS-EI $\mathrm{m} / z$ : calcd for $\mathrm{C}_{15} \mathrm{H}_{10} \mathrm{O}_{4} \mathrm{Se}+\mathrm{Na}$, 356.9642; found, 356.9622 .

Synthesis of Probe-OCI (7-Hydroxy-2,4-dimethyl-5(phenylselanyl)isoindoline-1,3-dione). A solution of triethylamine $(0.472 \mathrm{~mL}, 3.40 \mathrm{mmol})$ in acetonitrile $(5 \mathrm{~mL})$ was added dropwise to a solution of 5-methyl-4-(phenylselanyl)furan-2 $(5 \mathrm{H})$-one $(0.500 \mathrm{mg}, 2.80 \mathrm{mmol})$ and trimethylacetyl chloride $(0.417 \mathrm{~mL}, 3.40 \mathrm{mmol})$ in acetonitrile $(15 \mathrm{~mL})$, and the mixture was stirred at $60{ }^{\circ} \mathrm{C}$ for $14 \mathrm{~h}$. The precipitate of triethylamine hydrochloride was formed and filtered off. The filtrate was washed with $10 \%$ sodium carbonate, dried over $\mathrm{MgSO}_{4}$, and concentrated. The residue was concentrated and filtered through silica gel using a petroleum ether/EtOAc (4:1) solvent combination to afford the diene as a colorless oil. This was used directly for the next reaction. The above-mentioned diene $(0.600 \mathrm{~g}, 1.53 \mathrm{mmol})$ and $\mathrm{N}$-methylmaleimide $(0.150 \mathrm{~g}$, $1.53 \mathrm{mmol})$ were dissolved in diethyl ether $(3.0 \mathrm{~mL})$ under $\mathrm{N}_{2}$ and stirred overnight. Concentrated $\mathrm{H}_{2} \mathrm{SO}_{4}(1.5 \mathrm{~mL})$ at $263 \mathrm{~K}$ was added slowly to the resulting sticky liquid product. The cream-colored mixture was stirred for $5 \mathrm{~min}$ and then poured over crushed ice. The precipitated product was filtered off, washed by the addition of ice water, dried, and concentrated. The residue was purified by silica gel flash column chromatography using $n$-hexane/EtOAc $(3: 2)$ as an eluent to afford Probe-OCl $(0.597 \mathrm{~g}, 62 \%)$ as a yellow solid. ${ }^{1} \mathrm{H}$ NMR $\left(400 \mathrm{MHz}, \mathrm{CDCl}_{3}\right): \delta 7.58-7.56\left(\mathrm{~m}, 2 \mathrm{H}, \mathrm{H}_{12}, \mathrm{H}_{16}\right), 7.48-$ $7.32\left(\mathrm{~m}, 3 \mathrm{H}, \mathrm{H}_{13}, \mathrm{H}_{14}, \mathrm{H}_{15}\right), 6.62\left(\mathrm{~s}, 1 \mathrm{H}, \mathrm{H}_{6}\right), 3.06(\mathrm{~s}, 3 \mathrm{H}$, $\left.\mathrm{H}_{17}\right), 2.57\left(\mathrm{~s}, 3 \mathrm{H}, \mathrm{H}_{10}\right) ;{ }^{13} \mathrm{C}$ NMR $\left(100 \mathrm{MHz}, \mathrm{CDCl}_{3}\right): 169.8$ $\left(\mathrm{C}_{1}\right), 168.6\left(\mathrm{C}_{3}\right), 152.5\left(\mathrm{C}_{7}\right), 147.9\left(\mathrm{C}_{8}\right), 136.2\left(\mathrm{C}_{12,16}\right), 130.1$ $\left(\mathrm{C}_{13,15}\right), 129.4\left(\mathrm{C}_{5}\right), 129.3\left(\mathrm{C}_{9}\right), 127.8\left(\mathrm{C}_{14}\right), 126.8\left(\mathrm{C}_{11}\right)$, $121.9\left(\mathrm{C}_{6}\right), 112.3\left(\mathrm{C}_{4}\right), 23.5\left(\mathrm{C}_{17}\right), 15.0\left(\mathrm{C}_{10}\right) ;{ }^{77} \mathrm{Se}$ NMRS $\left(76.5 \mathrm{MHz}, \mathrm{CDCl}_{3}\right): 416.81 ; \mathrm{IR}\left(\mathrm{CHCl}_{3}\right) \nu_{\max }: 3434,3021$, 2933, 1758, 1694, 1615, 1578, 1439, 1385, 1285, 1252, 1204, $1177,1160,1108,1066,1005,928,871,757 \mathrm{~cm}^{-1} ; \mathrm{mp}=135-$ $140{ }^{\circ} \mathrm{C}$; MS-EI $\mathrm{m} / z$ : calcd for $\mathrm{C}_{16} \mathrm{H}_{14} \mathrm{NO}_{3} \mathrm{Se}+\mathrm{H}, 348.0139$; found, 348.0119.

Preparation of Samples. Stock solutions $(10 \mathrm{mM})$ of Probe-1 and Probe-OCl were prepared in dimethyl sulfoxide. The test solution was prepared by the addition of $15 \mu \mathrm{M}$ Probe-1 and Probe-OCl to $3 \mathrm{~mL}$ of PBS (10 mM, pH 7.4). After that, analytes were added, and a vortex mixer was used to make solutions homogeneous and ready for measurements. 
Measurement of Quantum Yield. The fluorescence quantum yield of Probe-1 and Probe-OCl before and after the reaction with $\mathrm{OCl}^{-}$was measured with fluorescein as a reference $(0.10 \mathrm{M} \mathrm{NaOH})$. The quantum yield was calculated with a comparative method according to the equation

$$
\mathbf{Q}=Q_{\mathrm{R}}\left(m / m_{\mathrm{R}}\right)\left(n / n_{\mathrm{R}}\right)
$$

where $Q_{R}$ is the fluorescence quantum yield of fluorescein, $m$ is the slope of the line obtained from the plot of the integrated fluorescence intensity versus absorbance, and $n$ is the refractive index of the solvent. Subscript $\mathrm{R}$ refers to the reference measurement (fluorescein).

Determination of LOD. LOD of probes was calculated from fluorescence titration measurements and blank measurements. To obtain the value for the slope, the values of fluorescence titration measurement intensity for Probe-1 (502 $\mathrm{nm}$ ) and Probe-OCl (523 nm) were used, respectively. Therefore, the detection limit was calculated with the following equation:

\section{Detection limit $=3 \sigma / k$}

where $\sigma$ is the standard deviation of 10 blank measurements and $k$ is the absolute value of the slope between the fluorescence intensity versus the $\mathrm{HOCl}$ concentration.

DFT Calculations. The molecular structures of Probe-OCl and Probe-OCl[O] and their HOMO-LUMO levels were calculated by DFT calculations by Gaussian 09 software (B3LYP method with 6-311g* basis set for Se only and 6$\left.31 \lg ^{*}\right)$.

Cell Maintenance and Live Cell Imaging. HeLa and U2 OS cells were cultured in Dulbecco's modified Eagle's medium (Gibco) or RPMI 1640 (Gibco) supplemented with $10 \%(\mathrm{v} / \mathrm{v})$ fetal bovine serum (Gibco) and $1 \%$ penicillin/ streptomycin $(100 \mathrm{U} / \mathrm{mL}$, Gibco). The HeLa cells were seeded at a density of $0.6 \times 10^{5}$ cells on sterilized $\mu$-slides (ibidi, München, Germany). After $24 \mathrm{~h}$, cells were washed with Dulbecco's PBS (D-PBS) two times. Next, $25 \mu \mathrm{M}$ Probe-OCl and $25 \mu \mathrm{M}$ MES-BOD-SePh were added to the cells, and the cells were incubated for $10 \mathrm{~min}$ at $37{ }^{\circ} \mathrm{C}$ and washed with $\mathrm{D}$ PBS two times. Live cell images were acquired on a Zeiss LSM 780 (Carl Zeiss, Jena, Germany) laser scanning confocal microscope, and $63 \times$ objective lens were used. The excitation wavelengths were 405 and $488 \mathrm{~nm}$, and the detection wavelengths were 410-495 and 500-563 nm.

Cell Viability Assays. The proliferation of HeLa cells was determined by the MTT assay (Sigma-Aldrich) using an established procedure. Briefly, the HeLa cells were seeded at a density of $1 \times 10^{4}$ cells into a 96-well plate $(n=4)$. Next, the cells were pretreated with Probe-OCl at various concentrations $(10,20,30,40$, and $50 \mu \mathrm{M})$ for $1-6 \mathrm{~h}$. After incubation, the proliferation reagent MTT $(0.5 \mu \mathrm{g} / \mathrm{mL})$ was added to each well, and the reagent-applied cells were incubated for $3 \mathrm{~h}$ at $37{ }^{\circ} \mathrm{C}$ and under $5 \% \mathrm{CO}_{2}$. Absorbances were measured using a Varioskan Flash (Thermo Scientific) at $540 \mathrm{~nm}$, and the reference wavelength was $690 \mathrm{~nm}$.

\section{ASSOCIATED CONTENT}

\section{S Supporting Information}

The Supporting Information is available free of charge on the ACS Publications website at DOI: 10.1021/acsomega.8b01571.
${ }^{1} \mathrm{H}$ NMR spectra of Probe-1 and Probe-OCl in $\mathrm{CDCl}_{3}$; ${ }^{13} \mathrm{C}$ NMR spectra of Probe- 1 and Probe-OCl in $\mathrm{CDCl}_{3}$; FT-IR spectra of Probe-1 and Probe-OCl; ESI-MS spectra of Probe-1 and Probe-OCl; UV-vis spectra of Probe-1 and Probe-OCl; fluorescence spectra for variable $\mathrm{pH}$ study of Probe-1 and Probe-OCl; fluorescence spectra of time-dependent study of Probe-1 and Probe-OCl; fluorescence study of ROS/ RNS and metal interferences of Probe-1 and Probe$\mathbf{O C l}$; experimental $\log P$ value of Probe-1 and ProbeOCl; DFT calculation results for Probe-OCl; cell viability assay of Probe-1 and Probe- $\mathbf{O C l}$; live cell imaging of Probe-OCl; reversibility studies of ProbeOCl among biothiols (PDF)

\section{AUTHOR INFORMATION}

\section{Corresponding Author}

*E-mail: dchurchill@kaist.ac.kr. Phone: +82-42-350-2845.

ORCID

David G. Churchill: 0000-0002-2520-4638

Present Address

"Semiconductor Material Division, LG Chemistry, 104-1, Munji-dong, Daejeon, Republic of Korea.

Author Contributions

${ }^{\perp}$ M.B.H., T.Y., and K.J.L. contributed equally.

Notes

The authors declare no competing financial interest.

\section{ACKNOWLEDGMENTS}

Prof. H. S. Park acknowledges the support from a grant from the National Research Foundation of Korea (2017R1A2B3011543). The Molecular Logic Gate Laboratory operated by Prof. D. G. Churchill acknowledges the support from the Mid-Career Researcher Program through the NRF (National Research Foundation) of Korea (NRF2014R1A2A1A11052980) funded by the MEST. T.Y. (LPDP/201412022313) acknowledges the Lembaga Pengelola Dana Pendidikan (LPDP) Indonesia Endowment Fund for the fellowship and KAIST for providing research facilities. Mahesh B. Halle acknowledges the BK21plus research fellowship. Y.K. acknowledges the IBS research fellowships and KAIST for providing research facilities. The research support staff at KAIST facilitated the acquisition of MS data.

\section{REFERENCES}

(1) McRae, R; Bagchi, P.; Sumalekshmy, S.; Fahrni, C. J. In Situ Imaging of Metals in Cells and Tissues. Chem. Rev. 2009, 109, 47804827.

(2) Thiagarajan, S.; Wu, Z.-Y.; Chen, S.-M. Amperometric determination of sodium hypochlorite at poly MnTAPP-nano Au film modified electrode. J. Electroanal. Chem. 2011, 661, 322-328.

(3) Lou, X.; Zhang, Y.; Qin, J.; Li, Z. Colorimetric hypochlorite detection using an azobenzene acid in pure aqueous solutions and real application in tap water. Sens. Actuators, B 2012, 161, 229-234.

(4) Yan, Y.; Wang, S.; Liu, Z.; Wang, H.; Huang, D. CdSe-ZnS Quantum Dots for Selective and Sensitive Detection and Quantification of Hypochlorite. Anal. Chem. 2010, 82, 9775-9781.

(5) Zhang, Z.; Deng, C.; Meng, L.; Zheng, Y.; Yan, X. A rhodamine hydrazide-based fluorescent probe for sensitive and selective detection of hypochlorous acid and its application in living cells. Anal. Methods 2015, 7, 107-114.

(6) Xu, Q.; Lee, K.-A.; Lee, S.; Lee, K. M.; Lee, W.-J.; Yoon, J. A Highly Specific Fluorescent Probe for Hypochlorous Acid and Its 
Application in Imaging Microbe-Induced HOCl Production. J. Am. Chem. Soc. 2013, 135, 9944-9949.

(7) D'Autréaux, B.; Toledano, M. B. ROS as signalling molecules: mechanisms that generate specificity in ROS homeostasis. Nat. Rev. Mol. Cell Biol. 2007, 8, 813-824.

(8) (a) Chan, J.; Dodani, S. C.; Chang, C. J. Reaction-based smallmolecule fluorescent probes for chemoselective bioimaging. Nat. Chem. 2012, 4, 973-984. (b) Yudhistira, T.; Mulay, S. V.; Lee, K. J.; Kim, Y.; Park, H.-S.; Churchill, D. G. Thiomaleimide Functionalization for Selective Biological Fluorescence Detection of Peroxynitrite as Tested in HeLa and RAW 264.7 Cells. Chem.-Asian J. 2017, 12, 1927-1934.

(9) Branzk, N.; Lubojemska, A.; Hardison, S. E.; Wang, Q.; Gutierrez, M. G.; Brown, G. D.; Papayannopoulos, V. Neutrophils sense microbe size and selectively release neutrophil extracellular traps in response to large pathogens. Nat. Immunol. 2014, 15, 1017-1025.

(10) Van de Bittner, G. C.; Bertozzi, C. R.; Chang, C. J. Strategy for Dual-Analyte Luciferin Imaging: In Vivo Bioluminescence Detection of Hydrogen Peroxide and Caspase Activity in a Murine Model of Acute Inflammation. J. Am. Chem. Soc. 2013, 135, 1783-1795.

(11) Winterbourn, C. C.; Hampton, M. B.; Livesey, J. H.; Kettle, A. J. Modeling the Reactions of Superoxide and Myeloperoxidase in the Neutrophil Phagosome. J. Biol. Chem. 2006, 281, 39860-39869.

(12) Wallace, D. C. Mitochondrial diseases in man and mouse. Science 1999, 283, 1482-1488.

(13) Koide, Y.; Urano, Y.; Hanaoka, K.; Terai, T.; Nagano, T. Development of an Si-Rhodamine-Based Far-Red to Near-Infrared Fluorescence Probe Selective for Hypochlorous Acid and Its Applications for Biological Imaging. J. Am. Chem. Soc. 2011, 133, $5680-5682$.

(14) Nauseef, W. M. Myeloperoxidase in human neutrophil host defence. Cell. Microbiol. 2014, 16, 1146-1155.

(15) Zhan, Z.; Liu, R.; Chai, L.; Li, Q.; Zhang, K.; Lv, Y. Turn-on Fluorescent Probe for Exogenous and Endogenous Imaging of Hypochlorous Acid in Living Cells and Quantitative Application in Flow Cytometry. Anal. Chem. 2017, 89, 9544-9551.

(16) Silva, M. T.; Correia-Neves, M. Neutrophils and macrophages: the main partners of phagocyte cell systems. Front. Immunol. 2012, 3, 174.

(17) Robinson, J. M. Reactive oxygen species in phagocytic leukocytes. Histochem. Cell Biol. 2008, 130, 281-297.

(18) Steinbeck, M. J.; Nesti, L. J.; Sharkey, P. F.; Parvizi, J. Myeloperoxidase and chlorinated peptides in osteoarthritis: potential biomarkers of the disease. J. Orthop. Res. 2007, 25, 1128-1135.

(19) Wu, S. M.; Pizzo, S. V. $\alpha 2$-Macroglobulin from Rheumatoid Arthritis Synovial Fluid: Functional Analysis Defines a Role for Oxidation in Inflammation. Arch. Biochem. Biophys. 2001, 391, 119126.

(20) Pak, Y.; Swamy, K.; Yoon, J. Recent Progress in Fluorescent Imaging Probes. Sensors 2015, 15, 24374-24396.

(21) Pattison, D. I.; Davies, M. J. Absolute rate constants for the reaction of hypochlorous acid with protein side chains and peptide bonds. Chem. Res. Toxicol. 2001, 14, 1453-1464.

(22) Andersen, J. K. Oxidative stress in neurodegeneration: cause or consequence? Nat. Rev. Neurosci. 2004, 10, S18-S25.

(23) Woods, A. A.; Linton, S. M.; Davies, M. J. Detection of HOClmediated protein oxidation products in the extracellular matrix of human atherosclerotic plaques. Biochem. J. 2003, 370, 729-735.

(24) Stocker, R.; Huang, A.; Jeranian, E.; Hou, J. Y.; Wu, T. T.; Thomas, S. R.; Keaney, J. F., Jr. Hypochlorous acid impairs endothelium-derived nitric oxide bioactivity through a superoxidedependent mechanism. Arterioscler. Thromb. Vasc. Biol. 2004, 24, 2028-2033.

(25) Daugherty, A.; Dunn, J. L.; Rateri, D. L.; Heinecke, J. W. Myeloperoxidase, a catalyst for lipoprotein oxidation, is expressed in human atherosclerotic lesions. J. Clin. Invest. 1994, 94, 437-444.

(26) Hazell, L. J.; Arnold, L.; Flowers, D.; Waeg, G.; Malle, E.; Stocker, R. Presence of hypochlorite-modified proteins in human atherosclerotic lesions. J. Clin. Invest. 1996, 97, 1535-1544.
(27) Sugiyama, S.; Okada, Y.; Sukhova, G. K.; Virmani, R.; Heinecke, J. W.; Libby, P. Macrophage myeloperoxidase regulation by granulocyte macrophage colony-stimulating factor in human atherosclerosis and implications in acute coronary syndromes. Am. J. Pathol. 2001, 158, 879-891.

(28) Hasegawa, T.; Malle, E.; Farhood, A.; Jaeschke, H. Generation of hypochlorite-modified proteins by neutrophils during ischemiareperfusion injury in rat liver: attenuation by ischemic preconditioning. Am. J. Physiol. Gastrointest. Liver Physiol. 2005, 289, G760-G767.

(29) van Golen, R. F.; Reiniers, M. J.; Vrisekoop, N.; Zuurbier, C. J.; Olthof, P. B.; van Rheenen, J.; van Gulik, T. M.; Parsons, B. J.; Heger, M. The Mechanisms and Physiological Relevance of Glycocalyx Degradation in Hepatic Ischemia/Reperfusion Injury. Antioxid. Redox Signaling 2014, 21, 1098-1118.

(30) Hayashi, K.-I.; Hosoe, H.; Raise, T.; Ohmori, K. Protective Effect of Erdosteine Against Hypochlorous Acid-induced Acute Lung Injury and Lipopolysaccharide-induced Neutrophilic Lung Inflammation in Mice. J. Pharm. Pharmacol. 2000, 52, 1411-1416.

(31) Gungor, N.; Knaapen, A. M.; Munnia, A.; Peluso, M.; Haenen, G. R.; Chiu, R. K.; Godschalk, R. W. L.; van Schooten, F. J. Genotoxic effects of neutrophils and hypochlorous acid. Mutagenesis 2010, 25, $149-154$

(32) Chen, X.; Tian, X.; Shin, I.; Yoon, J. Fluorescent and luminescent probes for detection of reactive oxygen and nitrogen species. Chem. Soc. Rev. 2011, 40, 4783-4804.

(33) Zhang, Y.-R.; Liu, Y.; Feng, X.; Zhao, B.-X. Recent progress in the development of fluorescent probes for the detection of hypochlorous acid. Sens. Actuators, B 2017, 240, 18-36.

(34) Yue, Y.; Huo, F.; Yin, C.; Escobedo, J. O.; Strongin, R. M. Recent progress in chromogenic and fluorogenic chemosensors for hypochlorous acid. Analyst 2016, 141, 1859-1873.

(35) Hu, J. J.; Ye, S.; Yang, D. Fluorescent Probes for $\mathrm{HOCl}$ Imaging. Isr. J. Chem. 2017, 57, 251-258.

(36) Xi, L.-L.; Guo, X.-F.; Wang, C.-L.; Wu, W.-L.; Huang, M.-F.; Miao, J.-Y.; Zhao, B.-X. A near-infrared ratiometric fluorescent probe for rapid and selective detection of hypochlorous acid in aqueous solution and living cells. Sens. Actuators, B 2018, 255, 666-671.

(37) Tian, F.; Jia, Y.; Zhang, Y.; Song, W.; Zhao, G.; Qu, Z.; Li, C.; Chen, Y.; Li, P. A HClO-specific near-infrared fluorescent probe for determination of Myeloperoxidase activity and imaging mitochondrial $\mathrm{HClO}$ in living cells. Biosens. Bioelectron. 2016, 86, 68-74.

(38) Sun, M.; Yu, H.; Zhu, H.; Ma, F.; Zhang, S.; Huang, D.; Wang, S. Oxidative Cleavage-Based Near-Infrared Fluorescent Probe for Hypochlorous Acid Detection and Myeloperoxidase Activity Evaluation. Anal. Chem. 2014, 86, 671-677.

(39) Deng, B.; Ren, M.; Kong, X.; Zhou, K.; Lin, W. Development of an enhanced turn-on fluorescent $\mathrm{HOCl}$ probe with a large Stokes shift and its use for imaging $\mathrm{HOCl}$ in cells and zebrafish. Sens. Actuators, $B$ 2018, 255, 963-969.

(40) Wei, P.; Yuan, W.; Xue, F.; Zhou, W.; Li, R.; Zhang, D.; Yi, T. Deformylation reaction-based probe for in vivo imaging of $\mathrm{HOCl}$. Chem. Sci. 2018, 9, 495-501.

(41) Yuan, L.; Lin, W.; Xie, Y.; Chen, B.; Song, J. Fluorescent Detection of Hypochlorous Acid from Turn-On to FRET-Based Ratiometry by a HOCl-Mediated Cyclization Reaction. Chem.-Eur. J. 2012, 18, 2700-2706.

(42) Xu, Q.; Lee, K.-A.; Lee, S.; Lee, K. M.; Lee, W.-J.; Yoon, J. A Highly Specific Fluorescent Probe for Hypochlorous Acid and Its Application in Imaging Microbe-Induced HOCl Production. J. Am. Chem. Soc. 2013, 135, 9944-9949.

(43) Cheng, X.; Jia, H.; Long, T.; Feng, J.; Qin, J.; Li, Z. A "turn-on" fluorescent probe for hypochlorous acid: convenient synthesis, good sensing performance, and a new design strategy by the removal of $\mathrm{C}=\mathrm{N}$ isomerization. Chem. Commun. 2011, 47, 11978-11980.

(44) Zhao, N.; Wu, Y.-H.; Wang, R.-M.; Shi, L.-X.; Chen, Z.-N. An iridium(III) complex of oximated $2,2^{\prime}$-bipyridine as a sensitive phosphorescent sensor for hypochlorite. Analyst 2011, 136, 22772282. 
(45) Emrullahoğlu, M.; Üçüncü, M.; Karakuş, E. A BODIPY aldoxime-based chemodosimeter for highly selective and rapid detection of hypochlorous acid. Chem. Commun. 2013, 49, 78367838.

(46) Chen, X.; Wang, X.; Wang, S.; Shi, W.; Wang, K.; Ma, H. A Highly Selective and Sensitive Fluorescence Probe for the Hypochlorite Anion. Chem.-Eur. J. 2008, 14, 4719-4724.

(47) Sun, Z.-N.; Liu, F.-Q.; Chen, Y.; Tam, P. K. H.; Yang, D. A Highly Specific BODIPY-Based Fluorescent Probe for the Detection of Hypochlorous Acid. Org. Lett. 2008, 10, 2171-2174.

(48) Hu, J. J.; Wong, N.-K.; Gu, Q.; Bai, X.; Ye, S.; Yang, D. HKOCl-2 Series of Green BODIPY-Based Fluorescent Probes for Hypochlorous Acid Detection and Imaging in Live Cells. Org. Lett. 2014, 16, 3544-3547.

(49) Kim, T.-I.; Park, S.; Choi, Y.; Kim, Y. A BODIPY-Based Probe for the Selective Detection of Hypochlorous Acid in Living Cells. Chem.-Asian J. 2011, 6, 1358-1361.

(50) Mulay, S. V.; Choi, M.; Jang, Y. J.; Kim, Y.; Jon, S.; Churchill, D. G. Enhanced Fluorescence Turn-on Imaging of Hypochlorous Acid in Living Immune and Cancer Cells. Chem.-Eur. J. 2016, 22, 9642-9648.

(51) Mulay, S. V.; Yudhistira, T.; Choi, M.; Kim, Y.; Kim, J.; Jang, Y. J.; Jon, S.; Churchill, D. G. Substituent Effects in BODIPY in Live Cell Imaging. Chem.-Asian J. 2016, 11, 3598-3605.

(52) Kim, Y.; Choi, M.; Manjare, S. T.; Jon, S.; Churchill, D. G. Diselenide-based probe for the selective imaging of hypochlorite in living cancer cells. RSC Adv. 2016, 6, 32013-32017.

(53) Manjare, S. T.; Kim, J.; Lee, Y.; Churchill, D. G. Facile mesoBODIPY Annulation and Selective Sensing of Hypochlorite in Water. Org. Lett. 2014, 16, 520-523.

(54) Brasaemle, D. L. Thematic review series: adipocyte biology. The perilipin family of structural lipid droplet proteins: stabilization of lipid droplets and control of lipolysis. J. Lipid Res. 2007, 48, 25472559.

(55) Bickel, P. E.; Tansey, J. T.; Welte, M. A. PAT proteins, an ancient family of lipid droplet proteins that regulate cellular lipid stores. Biochim. Biophys. Acta, Mol. Cell Biol. Lipids 2009, 1791, 419440.

(56) Stobart, A. K.; Stymne, S.; Höglund, S. Safflower microsomes catalyse oil accumulation in vitro: A model system. Planta 1986, 169, 33-37.

(57) Bartz, R.; Zehmer, J. K.; Zhu, M.; Chen, Y.; Serrero, G.; Zhao, Y.; Liu, P. Dynamic activity of lipid droplets: protein phosphorylation and GTP-mediated protein translocation. J. Proteome Res. 2007, 6, $3256-3265$

(58) Bozza, P. T.; Bakker-Abreu, I.; Navarro-Xavier, R. A.; BandeiraMelo, C. Lipid body function in eicosanoid synthesis: An update. Prostaglandins, Leukotrienes Essent. Fatty Acids 2011, 85, 205-213.

(59) Welte, M. A. Proteins under new management: lipid droplets deliver. Trends Cell Biol. 2007, 17, 363-369.

(60) Herms, A.; Bosch, M.; Ariotti, N.; Reddy, B. J. N.; Fajardo, A.; Fernández-Vidal, A.; Alvarez-Guaita, A.; Fernández-Rojo, M. A.; Rentero, C.; Tebar, F.; Enrich, C.; Geli, M.-I.; Parton, R. G.; Gross, S. P.; Pol, A. Cell-to-Cell Heterogeneity in Lipid Droplets Suggests a Mechanism to Reduce Lipotoxicity. Curr. Biol. 2013, 23, 1489-1496.

(61) (a) Hapala, I.; Marza, E.; Ferreira, T. Is fat so bad? Modulation of endoplasmic reticulum stress by lipid droplet formation. Biol. Cell 2011, 103, 271-285.

(62) Heaton, N. S.; Randall, G. Multifaceted roles for lipids in viral infection. Trends Microbiol. 2011, 19, 368-375.

(63) (a) Akiyama, M.; Sawamura, D.; Shimizu, H.; Nomura, Y.; Sugawara, M. Truncation of CGI-58 Protein Causes Malformation of Lamellar Granules Resulting in Ichthyosis in Dorfman-Chanarin Syndrome. J. Invest. Dermatol. 2003, 121, 1029-1034. (b) Shimabukuro, M. K.; Langhi, L. G. P.; Cordeiro, I.; Brito, J. M.; Batista, C. M. d. C.; Mattson, M. P.; Coelho, V. d. M. Lipid-laden cells differentially distributed in the aging brain are functionally active and correspond to distinct phenotypes. Sci. Rep. 2016, 6, 23795.
(64) Manjare, S. T.; Kim, Y.; Churchill, D. G. Selenium- and Tellurium-Containing Fluorescent Molecular Probes for the Detection of Biologically Important Analytes. Acc. Chem. Res. 2014, 47, 2985-2998.

(65) Gong, C.-b.; Ou, X.-x.; Liu, S.; Jin, Y.-1.; Huang, H.-r.; Tang, Q.; Hon-Wah Lam, M.; Chow, C.-f.; Tang, Q. A molecular imprintingbased multifunctional chemosensor for phthalate esters. Dyes Pigm. 2017, 137, 499-506.

(66) Halle, M. B.; Yudhistira, T.; Lee, W.-H.; Mulay, S. V.; Churchill, D. G. Diels-Alder and Stille Coupling Approach for the Short Protecting-Group-Free Synthesis of Mycophenolic Acid, Its Phenylsulfenyl and Phenylselenyl Analogues, and Reactive Oxygen Species (ROS) Probing Capacity in Water. Org. Lett. 2018, 20, 35573561.

(67) Niazi, J. H.; Prasad, D. T.; Karegoudar, T. B. Initial degradation of dimethylphthalate by esterases from Bacillusspecies. FEMS Microbiol. Lett. 2001, 196, 201-205.

(68) Wang, J.; Liu, P.; Qian, Y. Microbial degradation of di-n-butyl phthalate. Chemosphere 1995, 31, 4051-4056.

(69) Chen, G.; Fu, C.; Ma, S. Studies on electrophilic addition reaction of 2,3-allenoates with $\mathrm{PhSeCl}$. Tetrahedron 2006, 62, 44444452.

(70) Liu, S.-R.; Wu, S.-P. Hypochlorous Acid Turn-on Fluorescent Probe Based on Oxidation of Diphenyl Selenide. Org. Lett. 2013, 15, $878-881$.

(71) Balkrishna, S. J.; Hodage, A. S.; Kumar, S.; Panini, P.; Kumar, S. Sensitive and regenerable organochalcogen probes for the colorimetric detection of thiols. RSC Adv. 2014, 4, 11535-11538. 